PART 6

Conclusion 
Radhika Iyengar and Christina T. Kwauk - 9789004471818 Downloaded from Brill.com04/26/2023 09:38:50AM via free access 


\title{
Roadmap to Transformative Change and the Achievement of SDG 4.7
}

\author{
Radhika Iyengar and Christina T. Kwauk
}

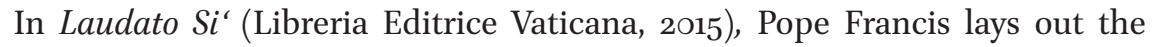
idea of modern anthropocentrism: that we have "elevated" humanity and the human spirit into a confrontational and domineering relationship toward creation. Modern anthropocentrism is the cause of the Covid-19 pandemic, and of much of the destruction in the planet. SDG 4.7 is not anthropocentric; it teaches us to appreciate and celebrate the planet and its people - through peace education, human rights education, education for sustainable development, and gender equality. It is a perfect vehicle for realizing Pope Francis's vision of humans' rising above themselves and caring for all living creations of this planet. SDG 4.7 is very much aligned with Pope Francis's notion of integral ecology, which essentially means learning to live in peace with all the cohabitants of the planet.

This book shows us how education can be a vehicle for achieving the social, economic, environment, peace, and security aims ${ }^{1}$ of Sustainable Development. It describes multiple pathways to what Pope Francis calls "consciousness-raising", a means of preventing further human-caused harm to the environment. The youth voices and teachers' perspectives in this book, together with those of researchers, school leadership, and global education actors, move us toward Pope Francis's ideal: ecological ethics that will drive much-needed changes, including how our education systems deliver education.

We hope that by the time this book reaches your hands, we will be "building back better" - or building back differently - after Covid-19. Surviving the Covid-19 pandemic has made us realize, in the words of Pope Francis, that

we have neglected and mistreated our ties with our Creator, with creation, and with our fellow creatures. But the good news is that an Ark awaits us to carry us to a new tomorrow. Covid-19 is our Noah moment, as long as we can find our way to the Ark of the ties that unite us: of love, and of a common belonging. (Pope Francis, 2020)

(C) UNESCO IBE, 2021 | DOI: 10.1163/9789004471818_021 
SDG 4.7 is the Ark that the education community has been waiting for; it offers a path toward sustainability, peace, resilience, and gender equality. It urges us to "cultivat[e] sound virtues" through which people will be empowered to "make a selfless ecological commitment" (Pope Francis, 2020). Pope Francis offers an ideological underpinning that is similar to that of Ubuntu ("I am because we are") that Gwekwerere and Shumba discuss in their chapter. With regard to this critical type of opportunity, whether we "waste it, or want it", is entirely up to us. This book presents some ideas on how we "build back" differently (see also UNESCO, 2O2O) and how we can use SDG 4.7 as the transformative vehicle that has until now been underutilized.

The book began by discussing the roadblocks to quality education in a time of climate change. How can some of the lessons that we learned from the chapters help us surmount those roadblocks?

A key roadblock is that eco-literacy is treated as a mere add-on to a global goal of basic literacy. Eco-literacy is, however, fundamental to our ability to survive, function, and thrive within planetary boundaries. Moreover, through a lens of eco-literacy, basic literacy can be reimagined. Children can learn basic reading and writing while learning with, and about, nature and our relationships with it and with each other. To include sticks to learn counting is not a new idea, or to use rocks to understand the concept of weight and physics, the weather to understand geographies and seasons, or man-made disasters to understand concepts of law and justice. Roemhild and Gaudelli in their chapter call for treating climate change education as an integral part of quality education. They suggest that education be considered incomplete if it doesn't address climate change education as a human rights issue in the context of our role as global citizens of planet earth. Bertolotti is inspiring when he describes how to incorporate the aspirations of SDG 4.7 into our mindset as educators, and how to include resilience, regenerative growth, and civic responsibility in our approach as we empower learners to seek balance with the environment.

Although the world has made many technological advances in past decades, from smartphones to medical breakthroughs to self-driving cars, we have lagged behind when it comes to preparing society for humanity's greatest existential threat, the climate crisis. We don't even have consistent metrics for assessing whether schools are providing quality education for climate action, let alone whether such education is actually being implemented equitably. A radical vision for education is needed at all levels of the education system, local and sub-national as well as national. Such a vision must ensure that our education systems are geared toward preparing society for the level of problem-solving and innovative thinking required to transform our economic, social, health, financial, and political systems to meet one of the greatest challenges of our time. 
Dougherty, a senior at UC Santa Barbara, explains that students in the United States are often left on their own to learn about climate change. Seckler, a rising sophomore at Columbia University notes that her engagement with climate and environmental education came from multiple community settings and not from her formal school education. According to these young people, the best form of climate change education involves making the learning personal and tying together different academic disciplines (as Singh also discusses in her chapter on transdisciplinary approaches). As with Dougherty's, the climate change educations of Seckler, Carlisle, and Bharadwaj were also self-driven, often with the encouragement of a few key mentors in their educational journey.

Students should not have to acquire a climate change education on their own. Educational institutions, in their role of preparing all students to function and thrive in a changing world, should make climate change education an integral part of what they offer. Hargis, McKenzie, and LeVert-Chiasson provide a framework showing how schools can do so in all areas, from teaching and learning to facilities and operations, school governance, and community partnerships. Creed and her co-authors discuss implementing a comprehensive vision in the university context, with five design elements through which this radical transformation can take shape: by leveraging the place, modeling the way, empowering action, capitalizing on the institution's strengths, and catalyzing social change. And Leicht and Byun discuss UNESCO's new ESD for 2030 framework as one mechanism for ensuring that all education systems around the world address the underlying sustainability challenges of our present day.

ESD has not been without its critics, because in its attempts to be a universally accepted concept, it has become so broad as to include the very neoliberal individualistic types of logic it is intended to counter. To separate ESD from a sharp analysis of what interconnected economic, social, and political systems are necessary if sustainability is to be achieved - and from the basic physics of planetary boundaries, as Dhara and Singh discuss - undercuts its ability to seed the transformations we need. A holistic treatment of ESD requires, therefore, a multidisciplinary and cross-sectoral approach that is complex and multidimensional. Since such an approach requires a major effort, many have chosen instead to cherry-pick some elements of ESD and ignore many important topics, such as climate justice. Climate justice issues, often messy, are often left to climate activists, for them to pursue outside of educational institutions. Sharma raises this issue in her chapter. She adds that formal education not only fails to engage with climate injustice, but it also, through its paucity of climate change education and its "commodification" of learning creates stresses on individuals and induces a level of eco-anxiety (which it also fails to address). 
Yet, addressing topics in climate justice is a key ingredient of the educational transformation that is much desired. Singh's chapter illustrates how such concepts can be integrated into the classroom, even for subjects typically not associated with such discussions. Larger transformative notions of degrowth and decolonization need also to be reflected in curricular design, as Dhara and Singh point out in their discussion of the incompatibility of SDG 4.7 with SDG 8 (on decent work and economic growth) and SDG 12 (on responsible consumption and production).

The separation of discussion of the environment, economic growth, consumption, and sustainable development from the discourse on education has done curriculum development a huge disservice; it allows for the perpetuation of values and norms that fuel overconsumption, human exceptionalism, and domination over others and over our natural world. Here is the real question that needs to be raised: How should we tackle such an unsustainable hidden curriculum?

Gwekwerere and Shumba propose an approach in the context of tackling the colonial elements of the curriculum in Zambia and Zimbabwe. They use the Afrocentric Ubuntu philosophy as a basis and lens through which to transform learning in the direction of thinking sustainably and taking action for climate change. Singh proposes three transdisciplinary "metaconcepts" (balance/ imbalance; planetary boundaries and limits; complexity) as starting points from which to uncover and reveal processes, relationships, and outcomes in our socio-ecological systems that typically remain out of sight and out of mind. Sharma takes her cues from the UK Student Climate Network and suggests that the intersectionality seen in the eco-activism of youth should be reflected also in formal education, specifically in the forms of phenomena-based learning for climate change and direct engagement with issues of climate justice. Her point about the need to strengthen teacher education on climate justice issues is in line with other research that similarly illustrates teachers' lack of awareness about climate justice issues, as well as their ambivalence about the educative potential of activism (McGregor \& Christie, 2021).

A global lack of systematic support for teachers' becoming change agents for the planet has amounted to an ongoing crisis. Gwekwerere and Shumba note that although the curriculum framework in Zambia and Zimbabwe may mention quality, it provides inadequate guidelines as to how teachers should put climate change education and ESD into operation in their classrooms.

A general perception is that developing teaching materials that cut across various subjects to provide a holistic treatment of climate change and ESD will take considerable time. For educators, this exercise seems impractical and infeasible, especially in contexts in which teachers already lack sufficient 
autonomy and support, such as the top-down Malaysian education system Balakrishnan describes. Single-subject teaching, with its insular exams and curriculums, thus tends to persist, to the neglect of education for sustainable development and its demands.

Teachers don't have to remain so unsupported. Hartwig's chapter on the Guatemala experience shows the power of democratically developing an innovative, context-responsive approach to integrated, ecology-based curriculum design. Having multiple stakeholders own the curriculum improves the chances of its successful adoption and implementation. Pihen González's chapter also touches on the lack of teacher support in the Americas and Asia. Although many lessons and teaching and learning materials may exist on YouTube and elsewhere, to plan a lesson that integrates core subject-area concepts with climate concepts remains daunting; teachers need frameworks and support if they are to make use of important innovative materials.

Luckily, Pihen González offers a good solution to this problem, with a discussion of practical pedagogical approaches that help put the teacher in the driver's seat. Helping teachers see how climate change and sustainable development topics can map against curricular standards, Pihen González shows us how the Issue-Academic-Standards framework not only can support teachers and help them produce blended lesson plans, but also can achieve muchneeded teacher buy-in, which is important for successful implementation. Shin and Akula also address the need for teacher support. Teachers are themselves products of a system in which environmental education has not been prioritized. Limited understanding of the depth and linkages of climate issues is rampant. Shin and Akula suggest that teacher training that clearly spells out how local actions translate into a local carbon footprint will help make climate topics come alive, and thus give teachers local examples to take into their classrooms. Gwekwerere and Shumba's discussion of "learning as connection" is also relevant: drawing linkages between the socio-cultural and socio-ecological form a basis of learning about personal-to-communal life-worlds. Such an exercise needs to start in teacher education colleges and be revisited at regular intervals in in-service teacher training. Balakrishnan's study from Malaysia suggests that the exam-dominated education system kills teachers' desires, and capacity, to give education a broader context and make it more relevant to students' lives. In other words, the top-down system prevents the teachers from being the drivers of an ESD agenda. A successful integration of ESD into the curriculum might have to go beyond the traditional top-down curricular model that is often associated with ESD.

This book has brought to light how individuals, especially the youth, have taken charge and become the torchbearers of sustainable development. Such 
individuals are passing the torch to others in their network at a rapid pace, while education institutions remain, as always, slow to react. Textbook development and curricular changes lag behind the urgency of the times. Ouryouths' reflections in this volume illustrate how youth are circumventing the education system and are taking it upon themselves to be the agents of real change. Bharadwaj, for instance, discusses the idea of creating avenues for students to engage in science exploration using an ecological lens. As an Eco Ambassador, he encourages schools to include families, friends, and communities in environmental problem-solving, to create life connections between what young people learn and explore in school and what happens beyond classroom walls. These students' actions are an important reminder that the education systems cannot relinquish their social responsibility to bring climate change issues to the fore. Nor should schools relinquish their role as the connective tissue within communities. In their current form, schools are trapped in tweaking their instruments (textbooks, curriculums) to address the rapidly changing climate, when what is required is a radical vision to vigorously tackle climate change head on.

Transformative education agendas thrive on radical ideas. Hargis, McKenzie, and LeVert Chiasson discuss some entry points for such ideas. They endorse a "whole institution" approach to transformation, which involves governance; teaching and learning; community partnerships; and facilities and operations. Specifically, they recommend establishing connections with local, national, and international networks and associations; integrating climate action within and across domains; and involving diverse peoples, knowledge, and perspectives in local action. These entry points are exemplified in Thakur's analysis of how a school engaged in a series of intentional activities calculated to address the disconnect between the school's academic goals and the climate. Thakur illustrates how the success of these eco-activities required a series of concerted efforts by multiple stakeholder groups, including the parent-teacher association, students, and the school principal. Her case study also points to the importance of school leadership in influencing sustainability through the effective use of school finances.

Transformative education encompasses not only formal education, but also the non-formal and informal sectors. Ocansey and Siakwa help us make the link to the informal economy and non-formal education through their account of eco-friendly vocational training and business development. The authors suggest that poverty and lack of access to government services have weakened opportunities for environmental vocations in communities located at the periphery of development, vocations that could help set a better course for those communities. Their chapter provides an example of how environmental 
education practices were built into a non-formal economy through the scaffolding of trainings in eco-focused businesses onto existing trainings of the informal labor force. Many more such initiatives need to be encouraged to ensure that non-formal technical and vocational programs can adequately up-skill both formal and informal labor forces toward a greener society.

Schools and curriculum are a reflection of the broader society that we live in. An egotistic, patriarchal, materialistic world with wasteful consumption and nary a care about the planet and its people casts a shadow over how we educate our children. Along these same lines, Dhara and Singh argue that the idea of limitless economic growth has brought us to this ecological crisis. They suggest that, at a minimum, a first step toward a transformative education is to come up with a functional definition of sustainability that could help up-skill students toward a sustainable future. But systematic change is what we should aim for, not merely a tweaking of a few existing elements of the education system.

As it currently stands, SDG 4.7 is a bucket list of all good things. Its wish list includes sustainable lifestyles, human rights, gender equality, promotion of a culture of peace and non-violence, global citizenship, appreciation of cultural diversity, and sustainable development. Each of these terms needs to be defined and put into a concrete context. Achieving the goals these terms stand for also requires pushing education systems to go beyond basic literacy and numeracy.

SDG 4.7, riddled as it is with vague and overly broad indicators, has no standardized benchmarks. Perhaps this looseness leaves room for countries to choose their own benchmarks and measures of progress - to flexibly define indicators at the national level.

Many examples of sustainability and global citizenship emerge, however, at local and sub-national levels. These get neither labeled nor recorded as SDG 4.7. Without mechanisms to measure progress on SDG 4.7 at the sub-national level and to ensure that such bottom-up measurement informs national-level indicators and international-level indicators, monitoring of SDG 4.7 is ineffective. To help account for, and measure, SDG 4.7, this book recommends, and exemplifies, the adoption of storytelling, centering of youth voices, documentation of local transformations, district evaluations, and school or classroom evaluations.

The people of this planet have driven it to imminent collapse; global warming is disrupting every aspect of our lives. Each summer is getting hotter, seasons are changing, wildfires rage as never before, safe water is scarce, and we are rapidly moving past $1.5^{\circ} \mathrm{C}$ (IPCC, 2018). It is time to get aggressive about curricular reforms and impatient with our education systems. This book hopes 
to provide the reader with many voices that have often been neglected or ignored. The voices come from stakeholders. The authors write from varied perspectives and through various lenses. The ideas in the book lead to various pathways forward, various ways of surmounting the roadblocks highlighted in its introduction. Certain paths may suit certain readers, depending on their situations and their roles. At the same time, the book also makes us realize the importance of the roles of all the various pathways in leading to a more Earth-friendly planet. We urge the readers to recognize the strength that lies in forming multiple pathways around the roadblocks. It's time for each one of us to live Ubuntu!

\section{Note}

1 For an informative graphic depiction of the aims of Sustainable Development, see the figure entitled "An integrated framework for realizing the 'future we want for all' in the post-2015 UN development agenda" in UN System Task Team (2012, p. 24).

\section{References}

IPCC [Intergovernmental Panel on Climate Change]. (2018). Global warming of $1.5^{\circ} \mathrm{C}$ [Summary for policymakers]. https://www.ipcc.ch/site/assets/uploads/sites/2/ 2019/o5/SR15_SPM_version_report_HR.pdf

Libreria Editrice Vaticana. (2015). Laudato Si': On care for our common home [Encyclical letter of the Holy Father Francis]. http://www.vatican.va/content/francesco/en/ encyclicals/documents/papa-francesco_20150524_enciclica-laudato-si.html

McGregor, C., \& Christie, B. (2021). Towards climate justice education: Views from activists and educators in Scotland. Environmental Education Research. https://doi.org/10.1080/13504622.2020.1865881

Pope Francis. (2020). Let us dream: The path to a better future. Simon \& Schuster.

UN System Task Team on the Post-2015 UN Development Agenda. (2012). Realizing the future we want for all: Report to the Secretary-General. https://www.un.org/ millenniumgoals/pdf/Post_2015_UNTTreport.pdf

UNESCO. (2020). Build back better: Education must change after COVID-19 to meet the climate crisis. https://en.unesco.org/news/build-back-better-education-mustchange-after-covid-19-meet-climate-crisis 